\title{
Azotun kışlık kolza çeşitlerinde verim ve verim unsurları üzerine etkisi*
}

\author{
Melih KÖYMEN ${ }^{1}$, Şevket Metin KARA ${ }^{1}$
}

1Tarla Bitkileri Bölümü, Ziraat Fakültesi, Ordu Üniversitesi, 52200, ORDU

*Bu araștırma Melih Köymen'in yüksek lisans tezinden üretilmiștir.

Alınıș tarihi: 10 Mart 2017, Kabul tarihi: 11 Ekim 2017

Sorumlu yazar: Şevket Metin KARA, e-posta: smkara@odu.edu.tr

\section{Öz}

Kışlık kolza, son yıllarda ülkemizde önemi her geçen gün artan bir yağ bitkisidir. Bu araştırma, bazı kışlık kolza çeşitlerinde azotun verim ve verim unsurları üzerine etkisini belirlemek amaciyla yürütülmüștür. Çalışmada ana parsellerde yer alan 3 kışlık kolza çeşidi (Bristol, Nelson ve ES Hydromel) ve alt parsellere yerleștirilen 5 azot dozu $(0,5,10,15$ ve 20 $\mathrm{kg} / \mathrm{da} \mathrm{N}$ ) kullanılmış ve tarla denemesi bölünmüş parseller deneme desenine göre 3 tekerrürlü olarak yürütülmüştür. Araştırmada azot dozlarının etkisi sadece dal sayısı ve tohum veriminde önemli bulunmuş, çeşitler arasındaki farklılık ve çeşit x azot interaksiyonu ise kapsül uzunluğu dışındaki bütün özelliklerde önemsiz çıkmıştır. Artan azot dozlarına paralel olarak, kolza çeşitlerinde tohum verimi linear olarak önemli derecede artmış ve $0 \mathrm{~kg} / \mathrm{da} \mathrm{N}$ dozunda $141.06 \mathrm{~kg} /$ da olan tohum verimi, $20 \mathrm{~kg} / \mathrm{da} \mathrm{N}$ dozunda, \% 64'lük bir artışla, en yüksek 231.86 $\mathrm{kg} /$ da seviyesine ulașmıștır. Çalıșmamızda azot dozu ile verim arasında doğrusal ilişki tespit edilmiş olması, kışlık kolza çeşitlerine azot tavsiyesinde bulunabilmek için, daha yüksek azot dozlarının yer aldığı çok yıllık araştırmaların yapılmasını gerekli kılmaktadır.

Anahtar kelimeler: Kanola, kışlık kolza, path analizi, verim komponentleri

\section{Effect of nitrogen on yield and yield components of winter rapeseed varieties}

\footnotetext{
Abstract

Winter rapeseed is becoming increasingly an important oilseed crop in Turkey in recent years.
}

This research was carried out to determine the effect of nitrogen on yield and yield components of some winter rapeseed cultivars. A field experiment was carried out with three rapeseed cultivars (Bristol, Nelson and ES Hydromel) allocated to main plots and five nitrogen doses $(0,5,10,15$ and $20 \mathrm{~kg} / \mathrm{da})$ allocated to sub-plots using a split plot design with three replications. The results revealed that the effect of nitrogen doses on yield was significant only for the number of branches and seed yield, but cultivar and cultivar $\mathrm{x}$ nitrogen interaction effects were significant just for capsule length. In accordance with increasing nitrogen doses, seed yield of winter rapeseed cultivars increased significantly and linearly, the seed yield of 141.06 $\mathrm{kg} / \mathrm{da}$ at control $(0 \mathrm{~kg} / \mathrm{da} \mathrm{N})$ reached to the maximum of $231.86 \mathrm{~kg} / \mathrm{da}$ at $20 \mathrm{~kg} / \mathrm{da} \mathrm{N}$ application, with a $64 \%$ increase. This linear relationship found between nitrogen rates and grain yield makes necessary to carry out some multi-year experiments with higher nitrogen doses to recommend nitrogen fertilizer for winter rapeseed varieties.

Key words: Canola, correlation, path analysis, winter rapeseed, yield components

\section{Giriş}

İnsan ve hayvan beslenmesindeki öneminin yanı sıra, sanayide çeşitli alanda hammadde olarak önemli bir yer işgal eden yağlı tohumlu bitkilerin kullanım alanı, tüketimi ve üretimi sürekli artmaktadır. Nitekim dünya kolza üretimi son 40-50 yıl içinde çok hızlı artış göstererek, yağlı tohum üretiminde soyadan sonra 2. siraya, bitkisel yă üretiminde ise palm ve soyadan sonra 3. sıraya yükselmiştir (Anonim, 2016). 
Dünyadaki gelișmelerin aksine, ülkemizde yağlı tohumlu bitkilerin ekim alanı ve üretimi son 25-30 yılda inişli-çıkışlı bir seyir göstermektedir. Bu dönemde yağlı tohumlu bitkilerin ekim alanı yaklaşık \% 25 oranında azalırken, yağlı tohum üretiminde \% 10’luk bir artış gerçekleșmiștir (Uyanık ve Kara, 2011). Ülkemizde üretilen yağlı tohumlu bitkiler, ihtiyaç duyulan bitkisel yağın sadece \% 30'unu karşılayabilmiş, geriye kalan \% 70'lik talep yağlı tohum veya ham yağ ithalatıla giderilmiştir (Öztürk, 2010; Uğur, 2012). Yağ açığının giderilmesi için, 2009 yılında 1,7 milyon ton yağlı tohum ve 1 milyon ton ham yağ ithal edilmiş ve karşılığında 2,2 milyar dolar ödenmiştir. Diğer taraftan 2014 yllındaki toplam tarım ürünleri ithalatında birinci sırayı 4.3 milyar dolar ile yağlı tohumlar ve türevleri almıştır (Alagöz ve Kara, 2015).

Kolza; kışlık ve yazlık tiplerinin bulunması, adaptasyon alanının çoğu yağ bitkilerine göre daha geniş olması, toprak istekleri yönünden fazla seçici olmaması ve mekanizasyona uygun olması gibi üstün özellikleri yönünden ülkemiz tarla tarımında yer alması gereken önemli bir bitkidir (Öztürk, 2000; Süzer, 2012). Bunların yanı sıra, yağ içeriğinin ve yağ asitleri yönünden insan beslenmesindeki değerinin yüksek oluşu ve biyoyakıt olarak kullanıma uygunluğu nedeniyle ülkemiz için stratejik öneme sahip yağ bitkilerinden birisidir (Odabaşı ve Taşkaya, 2004). Herhangi bir bölge için nispeten yeni olan bir bitki türünde öncelikli olarak o bölgeye uygun çeșitlerin ve üretim tekniklerinin belirlenmesi oldukça önemlidir (Alagöz ve Kara, 2015; Coşgun ve Öztürk, 2015). Bir bölgeye uygun çeşit ve yetiştirme tekniği önerisinde çok dikkatli olunmalı, farklı yer ve yılda yürütülen deneme bulgularına göre öneri yapılmalıdır. Yetiștirme tekniği uygulamaları arasında, özellikle verim ve kalite açısından, bitki tür ve çeşitlerinin besin elementi, özellikle azot, ihtiyacı en önemli etmen olarak kabul edilmektedir (Öztürk, 2010).

Kültür bitkilerinin artan azot dozlarına gösterdiği tepki sıcaklık, yağış, toprak yapısı, bitki sıklığı ve çeşit gibi çok sayıda faktöre bağlı olarak önemli değişiklik gösterebilmektedir. Yapılan araștırmalar artan azot dozlarına paralel olarak kolzada bitki gelişmesi ve tohum veriminin çok önemli derecede arttığını ortaya koymuştur (Başalma, 1999; Rathke et al., 2005; Öztürk, 2010). Azot, esas olarak bitki büyüme ve gelişmesini teşvik ederek bitki boyu, dal sayısı, kapsül sayısı, tohum sayısı ve tohum ağırlığı gibi verim unsurlarını artırmakta ve bunların sonucu olarak birim alan tane verimi de artmaktadır. Ancak gereğinden fazla azot uygulaması fayda yerine zarar getirir, verim ve kalite düşer ve ayrıca çevre kirliliği ile üretim ekonomisi açısından sakıncalı sonuçlar ortaya çıkar (Karaca ve Aytaç, 2007). Bu yüzden doğru azot dozunun belirlenmesi kolza tarımında çok önemli bir konudur ve bunun değişik bölge ve çeşitler için araştırmalarla ortaya konulması gereklidir. Ekonomisi ve tarımı çok büyük ölçüde findığa dayalı olan Ordu ilinde üretimde yer alabilecek tarla bitkilerinin ve uygun yetiştirme tekniklerinin belirlenmesi bitkisel ürün çeşitliliğinin sağlanması açısından çok önemlidir. Ancak bilimsel kaynaklarda Orta Karadeniz sahil kesiminde kolzada çeşit ve özellikle azotlu gübreleme konusundaki araştırmaların yeterli olmadığı görülmektedir. Buna uygun olarak bu çalıșma bazı kışlık kolza çeşitlerinde farklı azot dozlarının verim ve verim unsurları üzerine etkilerini incelemek amaciyla yürütülmüştür.

\section{Materyal ve Yöntem}

Çalışmada bitkisel materyal olarak, önceki araştırmaların sonuçlarına göre seçilen 3 kışlık kolza çeşidi (Bristol, Nelson ve ES Hydromel) kullanılmıştır. Deneme arazisinin toprağı hafif asidik, tuzsuz, kireçsiz ve killi-tınlı yapıda, organik madde ve potasyum yönünden zengin fakat fosfor bakımından yetersizdir. Denemenin yürütüldüğü 2010-2011 yetiştirme mevsimindeki toplam yağış $799.3 \mathrm{~mm}$, ortalama sicaklık 12.6 0C ve oransal nem \% 70.1 olmuştur (Anonim, 2011). Aynı dönemde uzun yıllar ortalamasına göre toplam yağış 877.9 mm, ortalama sıcaklık 11.6 0C ve oransal nem \% 72.2 olarak gerçekleşmiştir. Deneme sezonunda ekim, kasım ve aralık aylarındaki yağış miktarları uzun yıllar ortalamasından çok önemli farklılık göstermiştir. Uzun yıllar ortalaması ile mukayese edilince; ekim ayında yaklaşık iki kat fazla yağış düștüğü, aralık ayında ise düșen yağıș miktarının yarı yarıya azaldığı dikkati çekmektedir.

Tarla denemesi, Bölünmüş Parseller deneme deseninde 3 tekerrürlü olarak, Ordu İl Çevre ve Orman Müdürlügü arazisinde 2010-2011 yetiştirme sezonunda yürütülmüştür. Ana parsellerde çeşitlerin (Nelson, Bristol, Es Hydromel), alt parsellerde azot dozlarının $(0,5,10,15$ ve $20 \mathrm{~kg} /$ da $\mathrm{N})$ yer aldığ denemede, $30 \mathrm{~cm}$ aralığında ve $4 \mathrm{~m}$ uzunluğunda 5 sıradan oluşan alt parsellere tohum ekimi 28 Ekim 2010 tarihinde elle yapılmıştır. Kontrol (0 kg/da N) dışındaki tüm azot dozlarının yarısı ekimle beraber, 
diğer yarısı ilkbaharda çiçeklenme başlangıcından hemen önce uygulanmış ve tamamı ekimle birlikte olacak şekilde $6 \mathrm{~kg} / \mathrm{da}$ fosfor (P205) uygulaması yapılmıştır.

Hasat olgunluğuna erişen bitkiler 26-27 Haziran 2011 tarihinde, toprak seviyesinden orakla biçilmek suretiyle hasat edilmişlerdir. Her alt parselin sadece 3 orta sırası hasat edilmiş, kenarlardaki 1'er sıra ile parsel baş ve sonlarından $50 \mathrm{~cm}$ kenar sıra tesiri olarak ayrılmıştır. Alt parsellerden rastgele 10 bitki seçilmiş ve bitki boyu, dal sayısı, kapsül sayısı, kapsül uzunluğu, kapsülde tane sayısı ve bin tane ağırlığı verileri seçilen bu 10 bitki üzerinden alınmıştır. Verilere MSTAT-C istatistik programına göre varyans analizi uygulanmış, ortalamalar arasındaki farklılıkların önemlilik düzeyleri Duncan Çoklu Karşılaştırma testi ile gerçekleştirilmiştir. Ayrıca, artan azot dozları ile verim arasındaki ilişki regresyon analizi uyarınca incelenmiş ancak sadece linear ilișki önemli fakat quadratik ilişki önemsiz olduğu için, bu bulgulara yer verilmemiştir. İncelenen tüm özellikler arasındaki korelasyon katsayıları hesaplanmış ve path analizi ugulanarak verim unsurlarının tohum verimi üzerine olan doğrudan ve dolaylı etkileri belirlenmiştir.

\section{Bulgular}

Deneme metoduna uygun olarak yapılan varyans analizi sonuçlarına göe; çalışmadaki çeşitler arasında sadece kapsül uzunluğu açısından önemli farklılık çıkmış ancak bitki boyu, dal sayısı, kapsül sayısı, kapsülde tane sayısı, bin tane ağırlığı ve tohum veriminde çeşitler arasında önemli farklılık tespit edilememiştir. Artan azot dozlarının etkisi sadece dal sayısı ve tohum veriminde önemli bulunmuş, çeşit $\mathrm{x}$ azot interaksiyonu ise kapsül uzunluğu dışındaki bütün özelliklerde önemsiz olmuştur. Farklı azot dozlarında yetiştirilen kışlık kolza çeșitlerinde bitki boyu, dal sayısı, kapsül sayısı ve kapsül uzunluğu Çizelge 1'de ve kapsülde tane sayısı, bin tane ağırlığı ve tohum verimi değerleri Çizelge 2 'de verilmiştir.

Denemede yer alan kışlık kolza çeşitlerinde ölçülen bitki boyu değerleri $174.16 \mathrm{~cm}$ (Es Hydromel) ile $190.55 \mathrm{~cm}$ (Nelson) arasında değişmiştir (Çizelge 1). Kışlık kolza çeşitlerinin bitki boyu değerleri azot dozlarına göre $175.70 \mathrm{~cm}(0 \mathrm{~kg} / \mathrm{da} \mathrm{N})$ ile $185.17 \mathrm{~cm}$ $(20 \mathrm{~kg} / \mathrm{da} \mathrm{N})$ arasında değişiklik göstermektedir. Buna göre, etkisi istatistiki olarak önemsiz olsa da, azot dozları arttıkça kolzada bitki boyu artmaktadır.

Çizelge 1. Farklı azot dozlarında yetiştirilen kışlık kolza çeşitlerinde elde edilen bitki boyu (cm), dal sayısı, kapsül sayısı ve kapsül uzunluğu değerleri

\begin{tabular}{|c|c|c|c|c|c|c|}
\hline \multirow{2}{*}{ Çeşitler } & \multicolumn{5}{|c|}{ Azot Dozları (kg/da) } & \multirow{2}{*}{ Çeşitler ortalaması } \\
\hline & 0 & 5 & 10 & 15 & 20 & \\
\hline \multicolumn{7}{|c|}{ Bitki Boyu (cm) } \\
\hline Bristol & 180.73 & 171.97 & 174.13 & 170.67 & 182.67 & 176.03 \\
\hline Es Hydromel & 159.67 & 178.37 & 181.57 & 177.20 & 174.00 & 174.16 \\
\hline Nelson & 186.70 & 183.60 & 185.23 & 198.40 & 198.83 & 190.55 \\
\hline Azot dozları ortalaması & 175.70 & 177.98 & 180.31 & 182.09 & 185.17 & 180.25 \\
\hline \multicolumn{7}{|c|}{ Dal Sayısı } \\
\hline Bristol & 6.03 & 6.03 & 6.60 & 7.13 & 7.00 & 6.56 \\
\hline Es Hydromel & 3.67 & 5.07 & 4.63 & 5.33 & 6.30 & 5.00 \\
\hline Nelson & 5.60 & 6.33 & 6.47 & 7.10 & 6.97 & 6.49 \\
\hline Azot dozları ortalaması & $5.10 \mathrm{~B}^{*}$ & $5.81 \mathrm{AB}$ & $5.90 \mathrm{AB}$ & $6.52 \mathrm{~A}$ & $6.76 \mathrm{~A}$ & 6.02 \\
\hline \multicolumn{7}{|c|}{ Kapsül Sayısı } \\
\hline Bristol & 225.73 & 228.17 & 264.20 & 227.63 & 243.57 & 237.86 \\
\hline Es Hydromel & 150.97 & 190.77 & 173.47 & 216.63 & 240.83 & 194.53 \\
\hline Nelson & 181.80 & 189.40 & 200.60 & 253.53 & 243.43 & 213.75 \\
\hline Azot dozları ortalaması & 186.17 & 202.78 & 212.77 & 232.60 & 242.61 & 215.38 \\
\hline \multicolumn{7}{|c|}{ Kapsül Uzunluğu (cm) } \\
\hline Bristol & $6.26 \mathrm{~d}^{*}$ & $6.35 \mathrm{~cd}$ & $6.73 \mathrm{ad}$ & $6.64 \mathrm{ad}$ & $6.48 \mathrm{bd}$ & $6.49 \mathrm{~B}^{*}$ \\
\hline Es Hydromel & $7.37 \mathrm{a}$ & $7.07 \mathrm{ac}$ & $6.81 \mathrm{ad}$ & $6.93 \mathrm{ad}$ & $7.16 \mathrm{ab}$ & $7.07 \mathrm{~A}$ \\
\hline Nelson & $6.74 \mathrm{ad}$ & $6.57 \mathrm{bd}$ & $6.97 \mathrm{ad}$ & $7.14 \mathrm{ab}$ & $6.42 \mathrm{bd}$ & $6.77 \mathrm{AB}$ \\
\hline Azot dozları ortalaması & 6.79 & 6.66 & 6.84 & 6.90 & 6.69 & 6.78 \\
\hline
\end{tabular}

* : Aynı harfle gösterilen ortalamalar arasında istatistiki olarak fark yoktur. 
Kolza çeşitleri ortalaması olarak, azot dozundaki artışa uygun bir şekilde dal sayısı düzenli olarak artmış ve $0 \mathrm{~kg} / \mathrm{da} \mathrm{N}$ dozunda 5.10 olan dal sayısı 20 $\mathrm{kg} / \mathrm{da} \mathrm{N}$ dozunda 6.76 değerine ulaşmıştır. Kışlık kolza çeşitlerinin dal sayıları Es Hydromel için 5.00, Nelson için 6.02 ve Bristol için 6.56 olmuştur. Ayrıca, kışlık kolza çeşitlerinde kapsül sayısı 194.53 (Es
Hydromel) ile 237.86 (Bristol) arasında değişmiş ve kapsül sayıları azot dozunun artışıyla artmıştır. Nitekim, azot dozlarına göre en düşük kapsül sayısı 186.17 ile $0 \mathrm{~kg} /$ da $\mathrm{N}$ dozundan alınırken, en yüksek kapsül sayısı 242.61 ile $20 \mathrm{~kg} / \mathrm{da} \mathrm{N}$ dozundan alınmıştır.

Çizelge 2. Farklı azot dozlarında yetiştirilen kışlık kolza çeşitlerinde elde edilen kapsülde tane sayısı, bin tane ağırlığı ve tohum verimi değerleri değerleri

\begin{tabular}{|c|c|c|c|c|c|c|}
\hline \multirow{2}{*}{ Çeşitler } & \multicolumn{5}{|c|}{ Azot Dozları (kg/da) } & \multirow{2}{*}{$\begin{array}{c}\text { Çeşitler } \\
\text { ortalamas }\end{array}$} \\
\hline & 0 & 5 & 10 & 15 & 20 & \\
\hline \multicolumn{7}{|c|}{ Kapsülde Tane Sayısı } \\
\hline Bristol & 18.83 & 18.91 & 20.30 & 20.96 & 20.45 & 19.89 \\
\hline Es Hydromel & 20.88 & 19.13 & 17.45 & 18.51 & 20.28 & 19.25 \\
\hline Nelson & 19.51 & 19.26 & 19.66 & 20.65 & 18.69 & 19.55 \\
\hline Azot dozları ortalaması & 19.74 & 19.10 & 19.14 & 20.04 & 19.81 & 19.56 \\
\hline \multicolumn{7}{|c|}{ Bin Tane Ağırlığı (gram) } \\
\hline Bristol & 3.57 & 3.51 & 3.62 & 3.62 & 3.64 & 3.59 \\
\hline Es Hydromel & 3.78 & 3.73 & 3.69 & 3.84 & 3.96 & 3.80 \\
\hline Nelson & 3.78 & 3.79 & 4.07 & 4.26 & 4.11 & 4.00 \\
\hline Azot dozları ortalaması & 3.71 & 3.68 & 3.80 & 3.91 & 3.90 & 3.80 \\
\hline \multicolumn{7}{|c|}{ Tohum Verimi (kg/da) } \\
\hline Bristol & 152.39 & 165.11 & 194.33 & 173.89 & 201.35 & 177.41 \\
\hline Es Hydromel & 137.12 & 193.65 & 183.61 & 233.50 & 240.63 & 197.70 \\
\hline Nelson & 133.65 & 165.43 & 2013.07 & 215.03 & 253.59 & 196.16 \\
\hline Azot dozları ortalaması & $141.06 \mathrm{C}^{*}$ & $174.73 \mathrm{~B}$ & $197.00 \mathrm{~B}$ & $207.47 \mathrm{AB}$ & $231.86 \mathrm{~A}$ & 190.42 \\
\hline
\end{tabular}

* : Aynı harfle gösterilen ortalamalar arasında istatistiki olarak fark yoktur.

Araştırmada kapsül uzunluğu en az ve en fazla olan çeşitler sırasıyla $6.49 \mathrm{~cm}$ ile Bristol ve $7.07 \mathrm{~cm}$ ile Es Hydromel olmuştur. Buna karşılık azot dozları bakımından en düşük ve en yüksek kapsül uzunluğu değerleri sırasıyla $6.66 \mathrm{~cm}$ ile $5 \mathrm{~kg} / \mathrm{da} \mathrm{N}$ ve $6.90 \mathrm{~cm}$ ile $15 \mathrm{~kg} / \mathrm{da} \mathrm{N}$ ile uygulamasından elde edilmiştir. Kapsülde tane sayısı bakımından kıșlık kolza çeşitleri ve artan azot dozları arasında neredeyse hiç bir farklılık ortay açıkmamıştır. Kışlık kolza çeșitlerinin bin tane ağırlığı ortalamaları 3.59 (Bristol) ile 4.00 (Nelson) gram arasında değişiklik gösterirken, azot dozlarına göre bin tane ağırlığı değerleri 3.68 (5 kg/da N) ile 3.91 (15 kg/da N) gram arasında değişmiştir. Çalışmamızda yer alan kışlık kolza çeşitlerinin tohum verimleri azalan sirayla 197.70 kg/da (Es Hydromel), 196.16 kg/da
(Nelson) ve $177.41 \mathrm{~kg} / \mathrm{da}$ (Bristol) olarak tespit edilmiş, artan azot dozlarına paralel olarak kolza çeşitlerinin tohum veriminde belirgin ve düzenli bir artış gerçekleşmiştir. Nitekim $0 \mathrm{~kg} / \mathrm{da} \mathrm{N}$ dozunda $141.06 \mathrm{~kg} / \mathrm{da}$ olan tohum verimi, $20 \mathrm{~kg} / \mathrm{da} \mathrm{N}$ dozunda $231.86 \mathrm{~kg} /$ da seviyesine ulaşmıştır.

Kışlık kolza çeşitlerinin farklı azot dozlarında yetiştirildiği bu çalışmada; tohum verimi ile kapsül sayısı $\left(0.580^{* *}\right)$, bin tane ağırlı̆̆ $\left(0.429^{* *}\right)$, dal sayısı $\left(0.423^{* *}\right)$ ve bitki boyu $\left(0.390^{* *}\right)$ arasında çok önemli ve olumlu ilişkiler belirlenmiştir (Çizelge 3). Ayrıca; bitki boyu ile dal sayısı (0.599**) ve kapsül sayısı $\left(0.526^{* *}\right)$ ve dal sayısı ile kapsül sayısı $\left(0.688^{* *}\right)$ ve kapsül uzunluğu ile kapsülde tane sayısı $\left(0.502^{* *}\right)$ arasında olumlu ve çok önemli ilişkiler tespit edilmiştir.

Çizelge 3. Farklı azot dozlarında yetiştirilen kışlık kolza çeşitlerinde özellikler arasındaki korelasyon katsayıları

\begin{tabular}{|c|c|c|c|c|c|c|}
\hline Özellikler & Dal sayısı & Kapsül sayısı & Kapsül uzunluğu & Kapsülde tane s. & Bin tane ağırlığl & Tohum verimi \\
\hline Bitki boyu & $0.599^{* *}$ & $0.526^{* *}$ & -0.076 & -0.079 & 0.063 & $0.390^{* *}$ \\
\hline Dal sayısı & 1 & $0.688^{* *}$ & -0.254 & 0.177 & 0.153 & $0.423^{* *}$ \\
\hline Kapsül sayısı & & 1 & -0.051 & 0.196 & -0.019 & $0.580^{* *}$ \\
\hline Kapsül uzunluğu & & & 1 & $0.502^{* *}$ & 0.175 & 0.083 \\
\hline Kapsülde tane s. & & & & 1 & 0.033 & 0.038 \\
\hline Bin tane ağırlığ & & & & & 1 & $0.429^{* *}$ \\
\hline
\end{tabular}


Farklı azot dozlarında yetiştirilen kışlık kolza çeşitlerinde tohum verimi için yapılan path analizi sonuçları Çizelge 4'de verilmiştir. Tohum verimi üzerine doğrudan etkisi olumlu ve yüksek olan özellikler sırasıyla kapsül sayısı (0.542), bin tane ağırlığı (0.434) ve bitki boyu (0.181) olarak tespit Farklı azot dozlarında yetiştirilen kışlık kolza çeşitlerinde tohum verimi için yapılan path analizi sonuçları Çizelge 4'de verilmiştir. Tohum verimi üzerine doğrudan etkisi olumlu ve yüksek olan özellikler sırasıyla kapsül sayısı (0.542), kapsülde tane sayısı (0.434) ve bitki boyu (0.181) olarak tespit edilmiştir. Diğer taraftan, bitki boyu (0.255) ve dal sayısının (0.347) kapsül sayısı üzerinden tohum verimi üzerine olan dolaylı etkileri yüksek, fakat diğer özelliklerin tohum verimi üzerine dolaylı etkileri genellikle çok düşük ve hatta birçoğunda olumsuz yönde olmuştur.

Çizelge 4. Farklı azot dozları uygulanan kışlık kolza çeşitlerinde verim unsurlarının tohum verimi üzerine doğrudan ve dolaylı etkileri

\begin{tabular}{|c|c|c|c|c|c|c|c|}
\hline \multirow[b]{2}{*}{ Özellikler } & \multirow[b]{2}{*}{$\begin{array}{l}\text { Doğrudan } \\
\text { etkiler }\end{array}$} & \multicolumn{5}{|c|}{ Dolaylı Etkiler } & \multirow[b]{2}{*}{ Bin tane ağırlığı } \\
\hline & & $\begin{array}{l}\text { Bitki } \\
\text { Boyu }\end{array}$ & $\begin{array}{c}\text { Dal } \\
\text { sayısı }\end{array}$ & $\begin{array}{l}\text { Kapsül } \\
\text { sayısı }\end{array}$ & $\begin{array}{c}\text { Kapsül } \\
\text { uzunluğu }\end{array}$ & $\begin{array}{l}\text { Kapsülde tane } \\
\text { sayısı }\end{array}$ & \\
\hline Bitki boyu & 0.181 & --- & -0.032 & 0.255 & -0.012 & 0.035 & 0.012 \\
\hline Dal sayısı & -0.053 & 0.111 & ----- & 0.347 & -0.030 & 0.066 & -0.017 \\
\hline Kapsül sayısı & 0.542 & 0.085 & -0.034 & --- & -0.013 & -0.023 & -0.016 \\
\hline Kapsül uzunluğu & 0.119 & -0.019 & 0.013 & -0.059 & ---- & 0.076 & -0.047 \\
\hline Kapsülde tane sayısı & 0.434 & 0.015 & -0.008 & -0.029 & 0.021 & ---- & -0.003 \\
\hline Bin tane ağırlığ & -0.094 & -0.023 & -0.009 & 0.091 & 0.060 & 0.014 & --- \\
\hline
\end{tabular}

\section{Sonuçlar ve Tartışma}

Tarla bitkilerinde verim ve verim unsurları olarak kabul edilen bitki boyu, dal sayısı, kapsül sayısı, kapsül uzunluğu, tane sayısı ve bin tane ağırlığı gibi özellikler esas olarak genetik olarak belirlenmekle birlikte çevre şartları ve yetiştirme tekniği uygulamalarına göre önemli farklılıklar ortaya çıkabilmektedir. Bu çalışmada kışlık kolza çeşitleri arasında bitki boyu, dal sayısı, kapsül sayısı, kapsülde tane sayısı, bin tane ağırlığı ve tohum verimi açısından istatistikî olarak önemli farklılık ortaya çıkmamıştır. Çeşitler arasında sadece kapsül uzunluğu açısından önemli farlılıklar tespit edilmiştir. Kışlık kolza çeşitlerinde bitki boyu 174.16-190.55 cm, dal sayısı 5.00-6.56, kapsül sayısı 194.53-237.86, kapsül uzunluğu 6.49-7.07 cm, bin tane ağırlığı 3.59- $4.00 \mathrm{~g}$ ve tohum verimi 177.41 $197.70 \mathrm{~kg} /$ da arasında değişmiştir.

Ülkemizin farklı bölgelerinde yürütülen çeşit verim denemelerine göre kışlık kolza çeşitlerinde verim ve verim unsurları yönünden önemli farklar olabilmektedir. Nitekim Başalma (2004) Ankara koşullarında kışlık kolzada bitki boyunun 101.9$122.7 \mathrm{~cm}$, dal sayısının 3.2-4.3, ana sapta kapsül sayısının 29.5-42.0 ve tohum veriminin 162.8-263.8 $\mathrm{kg} / \mathrm{da}$ arasında değiştiğini rapor etmiştir. Buna karşılık Süzer (2007), Edirne koşullarında dokuz kışlık kolza çeşidinde bitki boyunun 125-150 cm, kapsül sayısının 119-129 ve tohum veriminin 202.3$284.7 \mathrm{~kg} / \mathrm{da}$ arasında değiştiğini bildirmektedir. Diğer taraftan Yozgat ekolojisinde bazı kışlık kolza çeşitlerinde bitki boyu 117.9-130.1 cm, kapsül sayısı 63.0-135.6 adet ve tohum verimi $221.3-419.0 \mathrm{~kg} / \mathrm{da}$ arasında değişmiştir (Gencer, 2010). Gizlenci ve ark. (2011) ise Samsun ilinde 52 kolza genotipi ile yaptıkları çalışmada bitki boyunun132.1-178.2 cm, dal sayısının 5.0-8.5, bin tane ağırlığının 2.9-4.9 g ve tohum veriminin ise $219.3-443.9 \mathrm{~kg} / \mathrm{da}$ arasında değiştiğini bildirmişlerdir. $\mathrm{Bu}$ araştırma sonuçlarından da açıkça görüldüğü gibi, farklı genotip ve çevre şartlarından en fazla etkilenen özelliklerin başında tohum verimi gelmektedir. $\mathrm{Bu}$ sonuçlara benzer şekilde tohum verimi Tekirdağ'da 142.6-230.5 kg/da (Sağlam ve Arslanoğlu, 1999), Diyarbakır'da 135-214 kg/da (Karaaslan, 1999), Isparta'da 218-287.2 kg/da (Baydar, 2005), Konya'da 162.3-211.5 kg/da (Bayraktar ve ark., 2007), ve Amasya'da 286.1-574.6 kg/da (Gizlenci ve ark., 2013) değerleri arasında değişmiştir.

Verim ve verim unsurları çeşit faktörünün yanı sıra ekim zamanı, bitki sıklığı ve azot dozları gibi yetiştirme tekniği uygulamalarına göre de çok önemli ölçüde farklılık gösterebilmektedir. Kolzada son yıllardaki pek çok çalışmada dar sıra aralıklarında daha yüksek verimlerin alındığı, buna karşılık geniş sıra aralıklarında tane veriminin azaldığı bildirilmektedir (Öztürk, 2000; Başalma ve ark., 2003; Farsak ve Kaynak, 2010). Örneğin Sargın (2012), farklı sıra arası uygulamalarına göre en yüksek tohum veriminin $324.94 \mathrm{~kg} /$ da ile $15 \mathrm{~cm}$ sıra aralığından alınmasına karşılık, en düşük tohum veriminin $186.34 \mathrm{~kg} /$ da ile $60 \mathrm{~cm}$ sıra aralığından 
elde edildiğini rapor etmektedir. Benzer şekilde, kışlık ve yazlık olarak ekilen kolzada ekim zamanı verim ve verim unsurlarında önemli değișimlerin oluşmasına yol açabilmektedir (Kural ve Özgüven, 1996; Öz, 2002; Zengin ve Uzun, 2005; Can, 2011). Nitekim Öztürk ve ark. (2008) tarafından yapılan bir araştırmada; yazlık olarak ekilen kolzada en yüksek tohum verimi en erken ekim olan 5 Nisan ekiminden alınmış, 20 Nisan ve 5 Mayıs ekimlerinde, 5 Nisan ekimine göre, tohum verimi sırasıyla \% 13 ve \% 25 oranında azalmıştır. Gürsoy ve ark. (2015), Ankara'da kışlık kolzada incelenen özelliklerde en yüksek değerlerin en erken ekim zamanı olan Eylül başındaki ekimden elde edildiğini, geciken ekimlerde tohum ve yağ veriminin önemli derecede azaldığını bildirmektedir.

Çalışmamızda artan azot dozlarının etkisi sadece dal sayısı ve tohum veriminde önemli çıkmış, diğer özelliklerde önemli bir etki tespit edilememiştir. Diğer taraftan, çeşit x azot interaksiyonu ise kapsül uzunluğu özelliği dışındaki bütün özelliklerde önemsiz bulunmuştur. Çalışmada artan azot dozlarında ölçülen bitki boyları $175.70 \mathrm{~cm}(0 \mathrm{~kg} / \mathrm{da}$ $\mathrm{N})$ ile $185.17 \mathrm{~cm}(20 \mathrm{~kg} / \mathrm{da} \mathrm{N}$ ) arasında değişiklik göstermiștir. Buna göre, etkisi istatistiki olarak önemsiz olmakla birlikte, azot dozu arttıkça bitki boyu da artmaktadır. Diğer taraftan azot dozundaki artışa paralel olarak dal sayısı da düzenli olarak artmış ve $0 \mathrm{~kg} / \mathrm{da} \mathrm{N}$ dozunda 5.10 olan dal sayısı 20 $\mathrm{kg} /$ da N dozunda 6.76 değerine ulaşmıștır. Benzer olarak, etkisi istatistiki olarak önemsiz olsa da kışlık kolza çeşitlerinde kapsül sayıları azot dozundaki artışla giderek artmış ve $0 \mathrm{~kg} / \mathrm{da} \mathrm{N}$ dozunda 186.17 olan kapsül sayısı, $20 \mathrm{~kg} / \mathrm{da} \mathrm{N}$ dozunda 242.61 düzeyine çıkmıştır. Diğer taraftan, artan azot dozlarına bağlı olarak kolza çeşitlerinde tohum verimi de düzenli bir şekilde artış göstermiştir. Buna göre; $0 \mathrm{~kg} /$ da $\mathrm{N}$ dozunda $141.06 \mathrm{~kg} /$ da olan tohum verimi, $20 \mathrm{~kg} / \mathrm{da} \mathrm{N}$ dozunda \% 164 oranında artarak $231.86 \mathrm{~kg} /$ da seviyesine ulaşmıştır.

Başalma (1999) tarafindan yürütülen bir araştırmada, kolzada tohum verimi artan azot dozlarına uygun olarak artmış ve en yüksek tohum verimi $290.49 \mathrm{~kg} / \mathrm{da}$ ile $12 \mathrm{~kg} / \mathrm{da} \mathrm{N}$ azot dozundan alınmıştır. Benzer şekilde Koç (2000), bazı kışlık kolza çeşitlerinde $0,7,14$ ve $21 \mathrm{~kg} /$ da olmak üzere 4 farklı azot dozunun verim ve verim unsurları üzerine etkisini incelediği çalışmasında tohum veriminin 74.05-256.6 kg/da arasında değiștiğini ve en yüksek tohum veriminin en yüksek azot dozundan elde edildiğini bildirmektedir. Buna benzer bir sonuç
Rathke et al. (2005) tarafından da ortaya konulmuş olup, en yüksek tohum verimi $240 \mathrm{~kg} \mathrm{~N} /$ ha dozunda elde edilmiştir. Genellikle azot dozları arttıkça kolzada bitki büyüme-gelişmesi, verim ve verim unsurları açısından daha yüksek değerler elde edilmektedir (Ngezimana ve Agenbag, 2013). AlSolaimani et al. (2015), $180 \mathrm{~kg} \mathrm{~N} / \mathrm{da}$ dozunda kontrol uygulamasına göre, bitki boyunda \%59, dal sayısında \%112, kapsüldeki tohum sayısında \%111 ve bin tane ağırlığında \%87 oranında artış gözlendiğini bildirmektedir.

Kolza tarımında, çok sayıda faktöre bağlı olarak farklılık göstermekle birlikte, genel olarak 12-24 $\mathrm{kg} / \mathrm{da} \mathrm{N}$ arasında değișen miktarlarda azot kullanılmaktadır. Genel kural olarak bütün tarla bitkilerinde, optimum azot dozuna yaklaşıldıkça azot kullanım etkinliği hızla azalmakta belirli bir değerin üstündeki azot dozları verim ve verim unsurlarını olumsuz yönde etkileyerek, tohum verimin azalmasına yol açmaktadır (Öztürk, 2010). Diğer taraftan, yüksek miktarda azotlu gübre kullanımı ayrıca üretim maliyetinin artmasına ve nihai gelirin azalmasına da sebep olmaktadır.

Yukarıdaki araştırmalardan farklı olarak Özer ve Peker (1998), 1994-1995 yıllarında en yüksek verimlerin 16 ve $24 \mathrm{~kg} / \mathrm{da} \mathrm{N}$ dozlarında alındığını, regresyon analiziyle fonksiyonel ilişki belirlenip ara gübre dozları tahmin edilince, en yüksek verimlerin sırasıyla 20 ve $23 \mathrm{~kg} / \mathrm{da} \mathrm{N}$ dozlarına karşılık geldiğini bildirmişledir. Buna karşılık regresyon modeline uygun olarak gübre ve tohum fiyatı üzerinden yapılan değerlendirmede, ekonomik optimum tane verimi açısından Erzurum koşullarında kolzaya verilecek azotlu gübre miktarının 10-13 kg sinırları arasında tutulması gerektiği önerilmiştir. Benzer şekilde beş farklı dozda $(0,50,100,150$ ve $200 \mathrm{~kg} \mathrm{~N} / \mathrm{ha})$ azot uygulamasının verim ve verim özellikleri üzerine etkisinin araştırıldığı bir çalışmada regresyon analizi uyarınca, $150 \mathrm{~kg} \mathrm{~N} /$ ha amonyum sülfat uygulaması, bitkinin azot ihtiyacını karşılaması açısından yeterli azot dozu olarak önerilmiştir (Öztürk, 2010).

Korelasyon analizi sonuçlarına göre; tohum verimi ile bitki boyu $\left(0.390^{* *}\right)$, dal sayısı $\left(0.423^{* *}\right)$, kapsül sayısı $\left(0.580^{* *}\right)$ ve bin tane ağırlığı $\left(0.429^{* *}\right)$ arasında çok önemli ve olumlu ilişkiler tespit edilmiştir. Diğer taraftan path analizi tohum verimi üzerine doğrudan etkisi olumlu ve yüksek olan özelliklerin sırasıyla kapsül sayısı (0.542), kapsülde tane sayısı (0.434) ve bitki boyu (0.181) olduğunu ortaya koymuştur. 
Diğer tarla bitkilerinde olduğu gibi kolzada da verim ve verim üzerine etkili olan faktörler arasındaki ilişkilerin ve karşılıklı etkileșimlerin iyi bilinmesi özellikle ıslah çalışmalarındaki başarı açısından önem taşımaktadır. Algan ve Aygün (2001), tek bitki verimi ile kapsül sayısı $\left(\mathrm{r}=0.45^{* *}\right)$, kapsülde tane sayısı $\left(\mathrm{r}=0.92^{* *}\right)$ ve bin tane ağırlığı $\left(\mathrm{r}=0.83^{* *}\right)$ arasında önemli korelasyonlar tespit edildiğini bildirmiştir. Ayrıca, path analizine göre bitki verimi üzerine doğrudan etkisi en yüksek özelliklerin kapsül sayısı ( $\mathrm{p}=0.28)$, kapsülde tane sayısı $(\mathrm{p}=0.64)$ ve bin tane ağırlığı $(\mathrm{p}=0.35)$ olduğu belirlenmiştir. Ankara koşullarında farklı ekim sıklıklarında tohum verimi ile ana saptaki kapsül sayısı ve kapsüldeki tohum sayısı arasında olumlu ilişkiler bulunmuştur (Başalma, 2006). Tohum verimine olumlu yönde en yüksek doğrudan etkisi olan özellikler bitki boyu, dal sayısı ve bin tane ağırlığıdır. Diğer taraftan Öztürk ve Ada (2009), farklı azot dozları uygulanan yazlık kolzada tohum verimi ile bitki boyu ( $\left.r=0.363^{*}\right)$ ve kapsül sayısı ( $\left.\mathrm{r}=0.501^{* *}\right)$ arasında pozitif ve önemli korelasyonlar tespit etmişlerdir. Path analizine göre; tohum verimi üzerine doğrudan olumlu etkisi en yüksek olan özellik \% 60.68 ile kapsül sayısı olup, bunu bitki boyu (\% 15.64) ve kapsülde tane sayısı (\% 10.75) izlemiştir.

Sonuç olarak; incelenen kışlık kolza çeşitlerinde artan azot dozlarıyla birlikte, tohum verimi önemli olarak artmış ve $0 \mathrm{~kg} / \mathrm{da} \mathrm{N}$ dozunda $141.06 \mathrm{~kg} / \mathrm{da}$ seviyesinden, $20 \mathrm{~kg} / \mathrm{da} \mathrm{N}$ dozunda, \%64'lük bir artışla, $231.86 \mathrm{~kg} /$ da seviyesine ulaşmıștır. Bir yıllık bu tez çalışmasında, azot dozları ile verim arasında sadece linear ilişki önemli çıkmış, buna karşılık azotverim arasında beklenen quadratik ilişkinin varlığı tespit edilememiştir. Bu yüzden, kışlık kolzaya azot önerisinde bulunmak için, daha yüksek azot dozların yer aldığı çok yıllık araştırmaların yapılması gerekmektedir.

\section{Kaynaklar}

Alagöz, N., Kara, Ş. M., 2015. Bazı kışlık kolza çeşitlerinin verim, verim öğeleri ve yağ oranlarının belirlenmesi. 11. Tarla Bitkileri Kongresi (7-10 Eylül 2015, Çanakkale) Poster Bildirileri, 506-509.

Algan, N., Aygün, H., 2001. Bazı fizyolojik kışlık kanola genotiplerinde verim ve verim komponentleri arasındaki ilişkiler. Ege Üniversitesi Ziraat Fakültesi Dergisi, 38 (1): 9-15.

Al-Solaimani, S. G., Alghabari, F., Ihsan, M. Z., 2015. Effect of different rates of nitrogen fertilizer on growth, seed yield, yield components and quality of canola
(Brassica napus L.) under arid environment of Saudi Arabia. International Journal of Agronomy and Agricultural Research, 7 (2); 1-7.

Anonim, 2011. Meteoroloji İşleri Genel Müdürlüğü, Ordu Meteoroloji İşleri Müdürlügü Kayıtları, Ordu.

Anonim, 2016. Oilseeds: World Markets and Trade. United States Department of Agriculture, Foreign Agricultural Services. USA.

Başalma, D., 1999. Azotlu gübrelemenin kolzanın verim ve verim öğelerine etkisi. Tarla Bitkileri Merkez Araştırma Enstitüsü Dergisi, (8): 1-2.

Başalma, D., Uranbey, S., Er, C., 2003. Bazı kışlık kolza (Brassica napus ssp. oleifera L.) çeşitlerinde farklı ekim sıklıklarının verim ve verim öğelerine etkisi. 5. Tarla Bitkileri Kongresi (13-17 Ekim 2003, Diyarbakır) Bildirileri Cilt II: 146-150.

Başalma, D., 2004. Kışlık kolza (Brassica napus ssp. oleifera L.) çeşitlerinin Ankara koşullarında verim ve verim öğeleri yönünden karşılaştırılması. Ankara Üniversitesi Ziraat Fakültesi Tarım Bilimleri Dergisi, 10 (2): 211-217.

Başalma, D., 2006. Kışlık kolzada (Brassica napus ssp. oleifera L.) ekim sıklığı, verim ve verim öğeleri arasındaki ilişkiler. Akdeniz Üniversitesi Ziraat Fakültesi Dergisi, 19 (2): 191-198.

Baydar, H., 2005. Isparta koşullarında kanola (Brassica napus L.) çeşitlerinin verim ve kalite özellikleri. Süleyman Demirel Üniversitesi Fen Bilimleri Enstitüsü Dergisi, 9 (3): 1-6.

Bayraktar, N., Öztürk, Ö., Mert, M., 2007. Konya koşullarında bazı kışlık kolza (Brassica napus L.) çeşitlerinin verim ve verim öğelerinin belirlenmesi. Türkiye 7. Tarla Bitkileri Kongresi (25-27 Haziran 2007, Erzurum) Bildirileri, Cilt II: 747-750.

Can, C., 2011. Van Ekolojik Koşullarında Farklı Ekim Zamanı Uygulamalarının Bazı Yazlık Kanola Çeşitlerinde Verim ve Verim Öğelerine Etkisi. Yüzüncü Yıl Üniversitesi Fen Bilimleri Enstitüsü (Basılmamış), Yüksek lisans Tezi, Van.

Coşgun, B., Öztürk, Ö., 2015. Konya koşullarında bazı kışlık kolza çeşitlerinde tohum verimi ve verim unsurlarının belirlenmesi. Türkiye 11. Tarla Bitkileri Kongresi (7-10 Eylül 2015, Çanakkale). Poster Bildiriler, 510-513.

Farsak, H., Kaynak, H. A., 2010. Kanola (Brassica napus ssp. oleifera $\mathrm{L}$.) çeşitlerinde sıra arası uzaklığının verim ve verim unsurları üzerine etkisi. Adnan Menderes Üniversitesi Ziraat Fakültesi Dergisi, 7 (1): 79-86.

Gencer, M. 2010. Yozgat İli Yerköy İlçesi Ekolojik Koşullarında Yetiştirilebilecek Kışlık Kanola 
Çeșitlerinin Belirlenmesi. Ordu Üniversitesi Fen Bilimleri Enstitüsü Yüksek Lisans Tezi, Ordu.

Gizlenci, Ș., Acar, M., Özçelik, H., Öner, E. K. 2011. Karadeniz Bölgesi sahil kuşağında bazı kolza çeșit Ve hatlarının verim ve verim unsurlarının saptanmasi. 9. Tarla Bitkileri Kongresi (12-15 Eylül 2011, Bursa) Bildirileri, 882-885

Gizlenci, Ș., Acar, M., Öner, E. K. 2013. Bazı kolza (Brassica napus ssp. oleifera L.) hat ve çeşitlerinin Amasya koşullarinda performanslarinin belirlenmesi. Türkiye X. Tarla Bitkileri Kongresi (10-13 Eylül 2013, Konya) Bildirileri, 280-284.

Gürsoy, M., Nofouzl, F., Başalma, D., 2015. Ankara koşullarında kışlık kolzada uygun ekim zamanının belirlenmesi. Tarla Bitkileri Merkez Araștırma Enstitüsü Dergisi, 24 (2):96-102.

Karaaslan, D. 1999. Diyarbakır koşullarında yetiştirilebilecek kolza çeşitlerinin saptanması üzerine bir araştırma. Türkiye 3. Tarla Bitkileri Kongresi (15-18 Kasım 1999, Adana) Poster Bildirileri, Cilt II: 328-333.

Karaca, E., Aytaç,, S., 2007. Yağ bitkilerinde yağ asitleri kompozisozyonu üzerine etkili faktörler. Ondokuz Mayıs Üniversitesi Ziraat F. Dergisi, 22(1):123-131.

Koç, H., 2000. Bazı kışlık kolza (Brassica napus L.) çeşitlerinde azotlu gübreleme. Gaziosmanpaşa Üniversitesi Ziraat Fakültesi Dergisi, 17 (1): 83-88.

Kural, A., Özgüven, M., 1996. Güneydoğu Anadolu Bölgesi koşullarında uygun kolza (Brassica napus L.) çeşitleri ve ekim zamanının saptanması üzerine bir çalıșma. Tarla Bitkileri Merkez Araştırma Enstitüsü Dergisi, 5 (1): 33-42.

Ngezimana, W., Agenbag, G. A., 2013. Effects of nitrogen (N) and sulphur (S) on canola (Brassica napus L.) vegetative and reproductive growth under controlled conditions. Global Journal of Agricultural Research and Reviews, 1 (1): 79-86.

Odabașı, S., Tașkaya, B. 2004, Kolza (Kanola). Tarımsal Ekonomi Araștırmaları Enstitüsü Dergisi,7(11):1-4.

Öz, M., 2002. Bursa Mustafakemalpaşa koşullarında farklı ekim zamanlarının kışlık kolza çeşitlerinde verim ve bazı verim unsurları üzerine olan etkileri. Uludağ Üniversitesi Ziraat Fak. Dergisi 16:1-13.

Özer, H., Peker, K., 1998. Erzurum ekolojik koşullarında kolza üretiminde optimum azot kullanımının belirlenmesi. Atatürk Üniversitesi Ziraat Fakültesi Dergisi, 29 (1), 50-57.

Öztürk, Ö., 2000, Bazı Kışlık Kolza Çeşitlerinde Farklı Ekim Zamanı ve Sıra Arası Uygulamalarının Verim, Verim
Unsurları ve Kalite Üzerine Etkileri. Selçuk Üniversitesi Fen Bilimleri Enstitüsü (Basılmamıș), Doktora Tezi, Konya.

Öztürk, Ö., Ada, R., Akınerdem, F., 2008. Konya koşullarında yazlık kolza çeşitlerinde uygun ekim zamanının belirlenmesi. Selçuk Üniversitesi Ziraat Fakültesi Dergisi, 22 (46): 6-17.

Öztürk, Ö., Ada, R., 2009. Yazlık kolzada farklı azot dozlarının verim İle morfolojik özellikler arasındaki ilişkilerinin belirlenmesi. Selçuk Tarım ve Gıda Bilimleri Dergisi, 23 (49): 24-49.

Öztürk, Ö., 2010. Effects of source and rate of nitrogen fertilizer on yield, yield components and quality of winter rapeseed (Brassica napus L.). Chilean Journal of Agricultural Research, 70 (1): 132-141.

Rathke, G. W., Christen, O., Diepenbrock, W., 2005. Effects of nitrogen source and rate on productivity and quality of winter oilseed rape (Brassica napus L.) grown in different crop rotations. Field Crops Research, 94; 103-113.

Sağlam, C., Arslanoğlu, F. 1999. Kışlık kolza çeşitlerinde ekim sıklıklarının verim ve verim unsurlarına etkisi. Türkiye 3. Tarla Bitkileri Kongresi (15-18 Kasım 1999, Adana) Sunulu Bildirileri, Cilt II,: 8891.

Sargın, S. 2012. Bitki sıklığının kışlık kolza çeşitlerinde verim, verim komponentleri ve yağ oranı üzerine etkisi. Ordu Üniversitesi Fen Bilimleri Enstitüsüı (Basılmamış) Yüksek Lisans Tezi,Ordu.

Süzer, S. 2007. Bazı kolza (Kanola) çeşitlerinin Edirne koşullarında verim ve verim unsurlarının belirlenmesi. 1. ulusal yağlı tohumlu bitkiler ve biyodizel sempozyumu (28-31 Mayıs 2007, Samsun) Bildirileri, 277-283.

Süzer, S. 2012. Kanola Yetiştiriciliği. Tarım Gündem Dergisi, 2 (10): 70-72.

Uğur, A. E. 2012. Türkiye'de yağlı tohum bitkileri üretimi ve bitkisel yağ sanayi, YABITTED I. Bitkisel Yağ Kongresi, 12-14 Nisan 2012, İstanbul.

Uyanık, M., Kara, Ș. M., 2011. Tarımsal üretim planlamasında ihmal edilen stratejik bitkiler: yağlı tohumlar. Uluslararası Katılımlı 1. Ali Numan Kıraç Tarım Kongresi ve Fuarı (27-30 Nisan 2011, Eskişehir).

Zengin, Ü., Uzun, B. 2005. Akdeniz Bölgesi sahil kuşağında yetiştirilen kolza bitkisinde farklı ekim zamanlarının verim ve verimle ilgili karakterlere etkisi. Türkiye VI. Tarla Bitkileri Kongresi (5-9 Eylül 2005, Antalya) Bildriileri, Cilt I: 217-222. 